\title{
PENGARUH EKSPOR PRODUK HALAL TERHADAP CURRENT ACCOUNT BALANCE DI INDONESIA ${ }^{1}$
}

\author{
Wina Annisafitri Purnama \\ Departemen Ekonomi Syariah-Fakultas Ekonomi dan Bisnis-Universitas Airlangga \\ Email: wina.annisafitri.purnama-2015@feb.unair.ac.id
}

Ilmiawan Auwalin

Departemen Ekonomi Syariah-Fakultas Ekonomi dan Bisnis-Universitas Airlangga

Email: auwalin@feb.unair.ac.id

\begin{abstract}
:
This research aims to measuring the effects of halalproduct export on current account balance (CAB) with some of control variables such as GDP growth, national currency to US dollar exchange rate, government expenditure, real interest rate and inflation. This research is quantitative approach using ARDL model. Based on time series data in quarterly, The results of the $t$ and $F$ tests in this study indicate that in the long run the export of halal industrial products and government expenditures partially has a significant positive effect, inflation has a significant negative effect, while the exchange rate and GDP growth do not have a significant effect on CAB. In the short term exports of halal industrial products and government expenditure have a significant positive effect, inflation and real interest rates have a significant negative effect, while the exchange rate and GDP growth do not have a significant effect on CAB.
\end{abstract}

Keywords: Halal Product Export, Current Account Balance, Halal Export

\section{PENDAHULUAN}

Perkembangan industri halal di Indonesia didasari oleh makin meningkatnya permintaan terhadap produk halal seiring dengan pertumbuhan masyarakat Islam di Indonesia. Populasi muslim akan meningkat sebesar 26,4 persen dari tahun 2013 hingga tahun 2030 (Pew Research Center's Forum on Religion \& Public Life). Hal ini mencerminkan pertumbuhan perekonomian Islam yang tinggi di masa yang akan datang seiring dengan pertumbuhan populasi masyarakat muslim di Indonesia yang sangat pesat tiap tahunnya. Pertumbuhan masyarakat muslim yang pesat ini membuat Indonesia menjadi negara dengan konsumen produk halal terbesar di dunia.
Indonesia merupakan salah satu negara muslim dengan tingkat konsumsi produk halal terbesar dunia. Konsumsi akan produk halal ini sebesar $7 \%$ berasal dari impor.

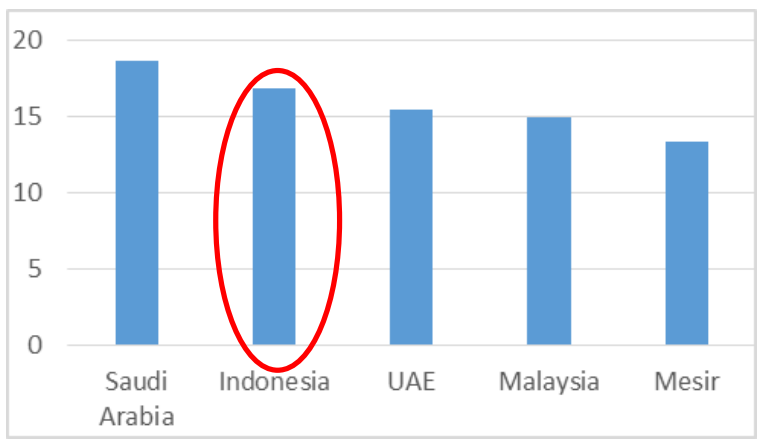

Gambar 1.

Lima Besar Importir Produk Halal (Miliar

Dolar Amerika Serikat)

Sumber: ITC Trade Map statistics, diakses 8 Januari 2019 (data diolah)

Gambar di atas merupakan urutan lima besar importir produk halalyang

\footnotetext{
${ }^{1}$ Jurnal ini merupakan bagian dari skripsi Wina Annisafitri Purnama, NIM: 041511433103, yang diuji pada tanggal 22 April 2019.
} 
didominasi oleh negara muslim seperti Saudi Arabia, Indonesia, Uni Arab Emirat (UAE), Malaysia dan Mesir. Indonesia terdapat pada urutan kedua dengan nilai impor sebesar 16,88 milliar Dolar Amerika Serikat. Indonesia memiliki tingkat impor produk halal sebesar $7 \%$ dari total pengeluaran masyarakat muslim dunia pada tahun 2017 (Indonesia Halal Economy Strategy Roadmap 2018/2019).

Industri halal merupakan arus perekonomian baru yang berpotensi mampu mendorong pertumbuhan ekonomi global. Pada kenyataannya Indonesia sendiri masih memiliki nilai ekspor produk halal lebih rendah dari nilai impornya

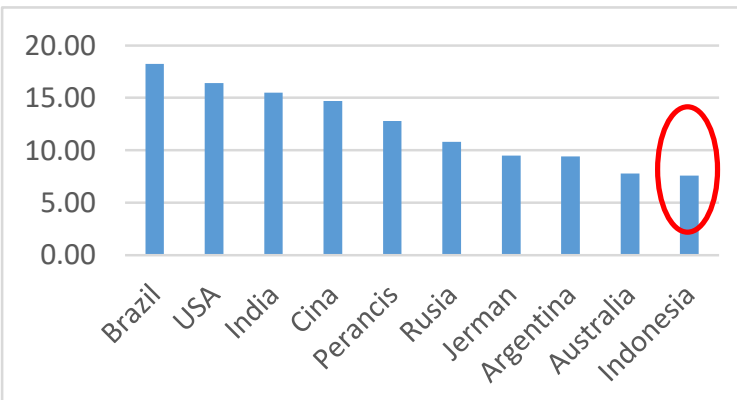

Gambar 2.

Sepuluh Besar Eksportir Produk Halal (Miliar Dolar Amerika Serikat)

Sumber: ITC Trade Map statistics, diakses 8 Januari 2019 (data diolah)

Gambar di atas merupakan urutan 10 besar negara eksportir produk halal yang didominasi negara yang mayoritas penduduknya adalah non-muslim. Indonesia berada pada urutan 10 dan merupakan eksporter tertinggi diantara negara-negara OKI lainnya yaitu sebesar 7,6 miliar Dolar Amerika Serikat dari total ekspor ke negara OKI secara keseluruhan (Indonesia Halal Economy and Strategy Roadmap 2018/2019).

Tingginya impor produk halal apabila tidak diimbangi dengan ekspor yang seimbang, maka akan menyumbang pelemahan posisi neraca pembayaran Indonesia serta menyumbang defisit transaksi berjalan akan terus berlangsung.

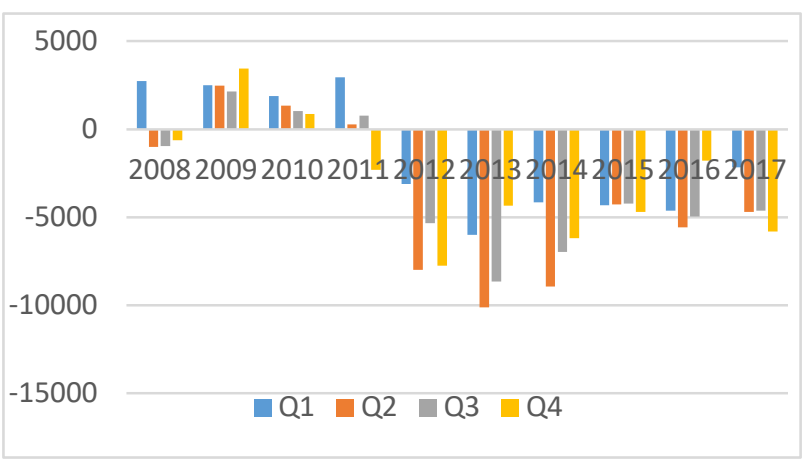

\section{Gambar 3.}

Transaksi Berjalan (Current account)

Indonesia (Juta Dolar Amerika Serikat)

Sumber : Bank Indonesia, diakses 8 Agustus 2018 (data diolah)

Gambar di atas menggambarkan neraca transaksi berjalan (current account balance) di Indonesia tahun 2008-2017. Pada triwulan IV tahun 2011 terjadi defisit neraca transaksi berjalan secara terus menerus yang belum pulih hingga saat ini. Lesunya kinerja ekspor karena turunnya permintaan global menjadi pendorong adanya defisit tersebut. Kenaikan tingkat impor dan menurunnya tingkat ekspor ini mencatat transaksi berjalan defisit sebesar 2,3 miliar Dolar Amerika Serikat pada triwulan IV- 
2011 yang bertahan hingga saat ini (www.bi.go.id).

Berdasarkan latar belakang diatas maka dapat dirumuskan permasalahan yaitu apakah terdapat pengaruh yang signifikan antara ekspor produk halal dan beberapa variabel kontrol inflasi, pertumbuhan Produk Domestik Bruto (PDB), nilai tukar, pengeluaran pemerintah dan suku bunga riilterhadap current account balance di Indonesia.

Tujuan penelitian ini adalah untuk mengetahui bagaimana pengaruh dari ekspor produk halaldan beberapa variabel kontrol seperti inflasi, pertumbuhan PDB, nilai tukar, pengeluaran pemerintah dan suku bunga riilterhadap current account balance di Indonesia.

\section{LANDASAN TEORI}

Industri halal dapat diartikan sebagai industri yang melakukan kegiatan produksi dengan memperhatikan segala rangkaian kegiatan dari pemilihan bahan baku, pengolahan bahan baku hingga pemilihan peralatan dan proses produksi hingga proses distribusi yang dilakukan berdasarkan syariat Islam. Hal ini diambil berdasarkan teori bawa aspek kehalalan tidak hanya dilihat ketika mengkonsumsi atau ketika membeli barang dan jasa tetapi melibatkan setiap aspek dan kegiatan di sepanjang rantai penawaran, dari supplier ke produsen dan seterusnya (Talib dkk, 2015:45). Industri halal terbagi atas beberapa sektor yaitu sektormakanan dan minuman, sektor obat- obatan dan kosmetik, sektor fashion, sektormedia dan rekreasisektor keuangan syariah dan sektor pariwisata syariah.

Tingginya permintaan produkproduk halaldisebabkan oleh tingkat pertumbuhan masyarakat muslim di dunia yang tinggi dengan jumlah populasi mencapai 2 miliar. Hal ini menyebabkan industri halal memegang peranan penting pada sistem perdagangan global melihat banyaknya negara muslim di dunia yang bergantung pada pasar internasional untuk memenuhi kebutuhan konsumsi mereka akan produk halal.

Neraca transaksi berjalan (current account balance) merupakan neraca perdagangan barang dan jasa suatu negara dengan negara lainnya dalam suatu periode waktu tertentu (Arifin dan Giana, 2007:87-89). Neraca transaksi berjalan memiliki pengaruh terhadap baik buruknya perekonomian suatu negara. Jika neraca transaksi mengalami defisit, maka suatu negara dapat mengalami krisis ekonomi. Maka dari itu neraca transaksi berjalan ini harus dijaga keseimbangannya dengan memperhatikan faktor-faktor yang mempengaruhinya guna menjaga kestabilan perekonomian suatu negara.

Hubungan antara ekspor dan neraca transaksi berjalan dapat digambarkan melalui rumus matematika sebagai berikut:

$C A=X-M$

Keterangan:

CA : Current account balance 
$\mathrm{X} \quad$ : Ekspor

M : Impor

Jika nilai ekspor lebih besar dari nilai impor neraca transaksi berjalan akan bernilai surplus, sedangkan apabila nilai ekspor lebih kecil daripada nilai impor maka neraca transaksi berjalan akan bernilai defisit.

Inflasi mempengaruhi current account balance melalui impor, inflasi yang tinggi akan menyebabkan harga barang impor lebih murah dari harga barang lokal dikarenakan harga produk domestik yang mengalami kenaikan secara terus menerus sehingga impor akan berkembang lebih cepat. Nilai impor yang berkembang lebih cepat dari nilai ekspor nya akan menyebabkan defisit neraca transaksi berjalan.

Pertumbuhan ekonomi suatu negara mempengaruhi neraca transaksi berjalan melalui impor yang mencerminkan permintaan domestik akan produk impor. Dalam keadaan perekonomian yang sedang baik, tingkat belanja konsumen kemudian tumbuh dan negara-negara akan membeli lebih banyak barang impor. Dalam keadaan ekonomi yang sedang mengalami resesi, tingkat belanja konsumen akan menurun sehingga tingkat pembelian akan barang impor juga akan menurun.

Nilai tukar memiliki hubungan dengan neraca transaksi berjalan melalui nilai ekspor dan impor. Depresiasi mata vang membuat ekspor lebih murah dibandingkan dengan impor sehingga orang asing akan membeli lebih banyak ekspor negara yang akan meningkatkan tingkat ekspor sehingga meningkatkan saldo neraca berjalan. Sebaliknya jika terjadi apresiasi mata vang yang membuat ekspor lebih mahal maka hal ini menyebabkan kenaikan permintaan impor yang akanmenurunkan saldo neraca transaksi berjalan.

Hubungan antara suku bunga dan neraca transaksi berjalan dapat dilihat melalui tabungan dan investasi. Peningkatan suku bunga akan meningkatkan tabungan dan mengurangi investasi serta penguatan (apresiasi) nilai tukar mata vang domestik yang kemudian akan menambah defisit neraca transaksi berjalan melalui peningkatan impor dan penurunan ekspor.

Hubungan

pengeluaran pemerintah dan neraca transaksi berjalan seringkali disebut sebagai twin deficit dikarenakan keduanya saling berhubungan pada saat keadaan defisit. Peningkatan budget deficit mendorong peningkatan aggregate demand dan pendapatan nasional serta menurunkan tabungan nasional yang mengakibatkan terjadinya peningkatan impor dan memperburuk current account. (Bagheri dkk, 2013).

\section{METODE PENELITIAN}

Penelitian ini menggunakan pendekatan penelitian kuantitatif deskriptif. Jenis variabel yang digunakan dalam penelitian ini yaituvariabel Independen (bebas) dan variabel 
dependen (terikat). Variabel dependen yang digunakan peneliti pada penelitian ini adalah ekspor produk industri halal (X1), inflasi (X2), pertumbuhan produk domestik bruto(pdb) (X3), nilai tukar (X4), suku bunga riil $(X 5)$ dan pengeluaran pemerintah (X6). Variabel dependen yang digunakan pada penelitian ini adalahCurrent account balance (y)

\section{Definisi Operasional}

Definisi operasional dari variabel yang akan digunakan dalam penelitian ini adalah:

1. Nilai ekspor produk industri halal didefinisikan sebagai nilai komoditas ekspor produk halal Indonesia. Data diambil sesuai dengan periode penelitian tahun 2008-2017 dan dinyatakan dalam satuan Dolar Amerika Serikat yang diperolah Laporan SEKI Bank Indonesia dari situs www.bi.go.id

2. Inflasi merupakan kenaikan hagaharga umum secara terus-menerus (Widjajanta dan Widyaningsih, 2007). Data diambil sesuai dengan periode penelitian tahun 2008-2017 dan dinyatakan dalam satuan persen yang diperoleh dari situs www.bi.go.id

3. Pertumbuhan PDB merupakan sebuah indikator untuk menilai kemajuan perekonomian suatu negara (Seran, 2016). Pertumbuhan ekonomi suatu negara diukur dari tingkat produk domestik bruto (PDB) negara tersebut. Data diambil sesuai dengan periode penelitian tahun 2008-2017 dan dinyatakan dalam satuan persen yang diperoleh dari situs fred.stlouisfed.org

4. Nilai Tukar Rupiah terhadap Dolar Amerika Serikatdidefinisikan sebagai nilai mata vang yang dapat ditukarkan dengan mata vang lain per unitnya atau harga satu mata vang dalam mata vang lain (Fabozzi dan Franco, 1996:724). Data diambil sesuai dengan periode penelitian tahun 2008-2017 dan dinyatakan dalam satuan rupiah yang diperoleh dari situs fred.stlovisfed.org.

5. Suku Bunga Riil adalah pembayaran bunga tahunan dari suatu pinjaman, dalam bentuk persentase dari pinjaman yang diperoleh dari jumlah bunga yang diterima tiap tahun dibagi dengan jumlah pinjaman(Karl dan Fair, 2001:635). Suku bunga riil didapatkan melalui perhitungan suku bunga nominal (BI Rate) dikurangi dengan tingkat inflasi. Data diambil sesuai dengan periode penelitian tahun 20082017 dan dinyatakan dalam satuan persen yang diperoleh dari situs www.bi.go.id

6. Pengeluaran pemerintah adalah seluruh pembelian atau pembayaran barang dan jasa untuk kepentingan nasional, seperti pembangunan gedung, jalan, jembatan, gaji pegawai negeri dan sebagainya (Samuelson, 1997). Data diambil sesuai dengan periode penelitian tahun 2008-2017 dan dinyatakan dalam satuan Rupiah yang diperoleh dari situs fred.stlovisfed.org.

7. Neraca transaksi berjalan (current account balance) merupakan neraca 
perdagangan barang dan jasa suatu negara dengan negara lainnya dalam suatu periode waktu tertentu (Arifin dan Giana, 2007:87). Data diambil sesuai dengan periode penelitian tahun 20082017 dan dinyatakan dalam satuan Dolar Amerika Serikat yang diperoleh dari Laporan SEKI Bank Indonesia dari situs www.bi.go.id

\section{Jenis dan Sumber Data}

Jenis data yang digunakan dalam penelitian ini adalah data sekunder berupa time series yang diperoleh dari laporan publikasi Global Islamic Economy Report, Bank Indonesia, Badan pusat statistik dan situs fred.stlouisfed.org. Dalam penelitian ini menggunakan data pada tahun 2008-2017

\section{Teknik Analisis}

Penelitian ini menggunakan teknik analisis time series dengan menggunakan E-views versi 10. Teknik analisis time series dipilih karena data yang digunakan dalam penelitian ini adalah data yang berupa runtutan waktu dengan periode tahun 2008-2017.

\section{Uji Kausalitas Granger}

Uji kausalitas granger digunakan untuk melihat arah hubungan dari variabel $x$ yaitu ekspor produk industri halal dan variabel y yaitu current account balance, apakah variabel $x$ mendahului variabel y atau sebaliknya.

Model Kausalitas granger digambarkan sebagai berikut:

Jika $X$ disebabkan oleh granger $Y$ :

$$
\begin{gathered}
\mathrm{Y}_{\mathrm{t}}=\beta_{0}+\beta_{1} \mathrm{Y}_{\mathrm{t}-1}+\ldots+\beta_{\mathrm{p}} \mathrm{Y}_{\mathrm{t}-\mathrm{p}}+\mathrm{a}_{1} \mathrm{X}_{\mathrm{t}-1}+\ldots+ \\
\mathrm{a}_{\mathrm{p}} \mathrm{X}_{\mathrm{t}-\mathrm{p}}+e_{\mathrm{t}}
\end{gathered}
$$

Jika $Y$ disebabkan oleh $X$ :

$$
\begin{aligned}
X_{t} & =\beta_{0}+\beta_{1} X_{t-1}+\ldots+\beta_{p} X_{t-p}+a_{1} Y_{t-1}+\ldots+ \\
& a_{p} Y_{t-p}+e_{t}
\end{aligned}
$$

Dimana:

$X$ = Nilai Ekspor produk industri halal

$Y=$ Current account balance

$\mathbb{e}=$ Error term

\section{Uji Stasionaritas Data}

Stasionaritas sebuah data dapat diteliti dengan menguji akar-akar unit (unit root). Pada penelitian ini metode yang digunakan adalah uji Augmented DickeyFuller (ADF). Model persamaan uji Dickeyfuller dapat dituliskan sebagai berikut:

$\Delta \mathrm{Y}_{\dagger}=\mathrm{a}_{0}+\mathrm{Y}_{\mathrm{t}-1}+\beta_{i} \sum_{i=1}^{j} \quad \Delta \mathrm{Y}_{t-i+1}+\varepsilon_{\dagger}$

Dimana:

$\Delta \mathrm{Y}_{\dagger}=$ Bentuk dari first difference

$a_{0}=$ intersep

$Y=$ Variabel yang diuji stasionaritasnya

$\mathrm{J}=$ panjang lag yang digunakan dalam model

$\varepsilon=$ error term

Pengujian hipotesis dilakukan dengan membandingkan nilai $p$-value dengan level of signification yaitu $1 \%, 5 \%$, atau $10 \%$. Apabila nilai p-value<level of signification, maka HO hipotesis yang mengatakan bahwa ada unit root ditolak dan sebaliknya.

\section{Uji Kointegrasi}

Kointegrasi terdiri dari pencocokan tingkat nonstasioneritas dari variabelvariabel dalam suatu persamaan dengan caramembuat error term dan residu dari 
persamaan stasioner dan menghindari persamaan dari setiap hasil regresi palsu (Studenmund, 2006:439).

\section{Estimasi Autoregressive Distributed Lag} (ARDL)

Teknik estimasi yang digunakan dalam penelitian ini adalah model regresi autoregressive distributed lag (ARDL). Penelitian ini melakukan regresi dengan model Autoregressive Distributed Lag (ARDL) dikarenakan apabila setelah dilakukan uji stasionaritas beberapa variabel stasioner pada tingkat yang berbeda, pada level dan first difference. ARDL merupakan metode berbasis OLS yang dapat diaplikasikan pada variabel yang tidak stasioner pada level maupun variabel-variabel yang stasioner pada level yang berbeda (Shrestha dan Bhatta, 2018).

\section{Uji lag optimal}

Uji lag optimal dilakukan untuk penentuan panjang kelambanan (lag) yang tepat dalam model ARDL. Pemilihan model ARDL terbaik dengan kombinasi lag yang optimal pada penelitian ini dilihat berdasarkan Akaike Info Criteria (AIC).

Uji Autokorelasi dan Uji Heteroskedastisitas

Pada penelitian ini uji asumsi yang akan dilakukan berupa asumsi autokorelasi dan asumsi heteroskedastisitas.

\section{Bound test}

Bound test merupakan pengujian yang dilakukan untuk mengetahui adakah hubungan jangka panjang (kointegrasi) antar variabel-variabel ARDL tersebut.

\section{Error-correction term}

Pengujian ini digunakan untuk mengetahui seberapa besar kecepatan model menuju tingkatkeseimbangan

\section{Pengujian Signifikansi}

\section{Uji t-statistik}

Uji t-statistik atau uji parsial digunakan untuk menentukan pengaruh dari variabel-variabel bebas secara individual terhadap variabel terikatnya dengan caramelihat p-value dan membandingkannya dengan tingkat signifikansi.

Hipotesis dari uji t-statistik adalah sebagai berikut:

a. $H O: \beta_{i}=0$ (tidak ada pengaruh)

b. $\mathrm{Hl}: \beta_{i \neq}$ (terdapat pengaruh)

\section{Uji F-statistik}

Uji F-statistik atau uji simultan digunakan untuk menentukan pengaruh dari variabel-variabel bebas secara simultan atau secara bersama-sama terhadap variabel terikatnya dengan caramelihat p-value dan membandingkannya dengan tingkat signifikansi.

Hipotesis dari uji F-statistik adalah sebagai berikut:

a. $\mathrm{HO}: \beta_{i}=0$ (tidak ada pengaruh)

b. $\mathrm{Hl}: \beta_{\mathrm{i} \neq}$ (terdapat pengaruh)

\section{Analisis Koefisien Determinasi}

Koefisien determinasi $\left(R^{2}\right)$ digunakan untuk menunjukan seberapa besar kemampuan variabel bebas dalam 
menjelaskan variabel terikatnya. Nilai koefisien determinasi berada diantara 0-1.

\section{HASIL DAN PEMBAHASAN}

\section{Uji Kausalitas Granger}

Sebelum dilakukan uji kausalitas granger diperlukan uji kointegrasi terlebih dahulu antara variabel ekspor produk industri halal dan variabel current account balance, apabila kedua variabel ini terkointegrasi maka terdapat hubungan antara keduanya sehingga selanjutnya dapat dilakukan uji kausalitas granger antara variabel ekspor produk industri halal dan current account balance.

Tabel 1.

\section{Hasil Uji Kointegrasi Ekspor dan CAB}

\begin{tabular}{|c|c|c|}
\hline Uji Kointegrasi & P-value & t-statistic \\
\hline $\begin{array}{c}\text { Augmented } \\
\text { Dickey-Fuller test }\end{array}$ & 0,0097 & $-3,631117$ \\
\hline
\end{tabular}

Sumber: Data Olahan Eviews

Hasil uji kointegrasi diatas menunjukan bahwa variabel ekspor produk industri halal dan current account balance terkointegrasi karena memiliki probabilitas $<0,01$ sehingga dapat dilanjutkan dengan pengujian kausalitas granger.

Tabel 2.

Hasil Uji Kausalitas Granger

\begin{tabular}{|l|c|c|}
\hline & F-statistik & Prob \\
\hline $\begin{array}{l}\text { Secara granger } \\
\text { perubahan CA } \\
\text { menyebabkan } \\
\text { perubahan } \\
\text { Ekspor }\end{array}$ & 1,30064 & 0,2860 \\
\hline $\begin{array}{l}\text { Secara granger } \\
\text { perubahan } \\
\text { Ekspor }\end{array}$ & 8,53934 & 0,0010 \\
\hline
\end{tabular}

\begin{tabular}{|l|l|l|}
\hline $\begin{array}{l}\text { mempengaruhi } \\
\text { perubahan CA }\end{array}$ & & \\
\hline
\end{tabular}

Sumber: Data Olahan Eviews

Berdasarkan hasil uji kausalitas granger pada tabel diatas dapat diartikan bahwa hubungan kausalitas granger current account terhadap ekspor secara statistik tidak signifikan pada level 5 persen (prob > 0,05). Hubungan kausalitas granger ekspor terhadap current account secara statistik signifikan pada level 5 persen (prob < 0,05). Maka dapat disimpulkan bahwa ada hubungan satu arah dari ekspor produk industri halal terhadap CAB

Uji Stasionaritas

Tabel 3.

Hasil Uji Stasioneritas

\begin{tabular}{|l|c|c|l|}
\hline \multirow{2}{*}{ Variabel } & \multicolumn{3}{|c|}{ Tingkat Stasioneritas } \\
\cline { 2 - 4 } & \multicolumn{3}{|c|}{ Level } \\
\cline { 2 - 4 } & t-statistik & Prob & \multicolumn{1}{|c|}{ Ket } \\
\hline CA & $-4,465320$ & 0,0010 & Stasioner \\
\hline Ekspor & $-4,156120$ & 0,0026 & Stasioner \\
\hline $\begin{array}{l}\text { Pertumbuh } \\
\text { an PDB }\end{array}$ & $-4,009125$ & 0,0036 & Stasioner \\
\hline $\begin{array}{l}\text { Nilai Tukar } \\
\text { Inflasi }\end{array}$ & $-0,721324$ & 0,8295 & $\begin{array}{l}\text { Tidak } \\
\text { Stasioner }\end{array}$ \\
\hline $\begin{array}{l}\text { Suku Bunga } \\
\text { Riil }\end{array}$ & $-2,223785$ & 0,2015 & $\begin{array}{l}\text { Tidak } \\
\text { Stasioner }\end{array}$ \\
\hline $\begin{array}{l}\text { Pengeluara } \\
\mathbf{n} \\
\text { Pemerintah }\end{array}$ & $-1,869240$ & 0,0000 & Stasioner \\
\hline & & $\mathbf{3}$ & $\begin{array}{l}\text { Tidak } \\
\text { Stasioner }\end{array}$ \\
\hline & $-9,443542$ & 0,0000 & Stasioner \\
\hline CA & \multicolumn{2}{|c|}{ First Difference } \\
\hline
\end{tabular}




\begin{tabular}{|l|l|l|l|}
\hline Ekspor & $-3,580401$ & 0,0111 & Stasioner \\
\hline $\begin{array}{l}\text { Pertumbuh } \\
\text { an PDB }\end{array}$ & $-3,633132$ & 0,0100 & Stasioner \\
\cline { 1 - 2 } Nilai Tukar & $-5,322687$ & 0,0001 & Stasioner \\
\cline { 4 - 4 } Inflasi & $-5,994542$ & 0,0000 & Stasioner \\
\cline { 1 - 1 } $\begin{array}{l}\text { Suku Bunga } \\
\text { Riil }\end{array}$ & $-7,126796$ & 0,0000 & Stasioner \\
\cline { 1 - 3 } $\begin{array}{l}\text { Pengeluara } \\
\mathbf{n} \\
\text { Pemerintah }\end{array}$ & $-7,703853$ & 0,0000 & Stasioner \\
\cline { 2 - 4 } & & & \\
\hline
\end{tabular}

Sumber: Data Olahan Eviews

Hasil uji stasioner diatas menunjukan bahwa beberapa variabel seperti current account, ekspor, pertumbuhan PDB dan suku bunga riil stasioner pada level karena semua variabel memiliki probabilitas lebih kecil dari nilai level of significant yaitu sebesar $1 \%$, $5 \%$ dan $10 \%$ pada level. Sedangkan beberapa variabel seperti nilai tukar, inflasi dan pengeluaran pemerintah tidak stasioner pada level karena memiliki probabilitas lebih besar dari nilai level of significant yaitu sebesar $1 \%, 5 \%$ dan $10 \%$. Ketiga variabel ini stasioner ketika dilakukan pengujian pada tingkat first difference.

Uji Kointegrasi

Tabel 4.

Hasil Uji Kointegrasi

\begin{tabular}{|c|c|c|}
\hline Uji Kointegrasi & Probability & t-statistic \\
\hline $\begin{array}{c}\text { Augmented Dickey- } \\
\text { Fuller test }\end{array}$ & 0,0000 & $-6,784755$ \\
\hline \multicolumn{3}{|c|}{ Mackinnon Critical Value } \\
\hline $1 \%$ & $5 \%$ & $10 \%$ \\
\hline$-3,610453$ & $-2,938987$ & $-2,607932$ \\
\hline
\end{tabular}

Sumber: Data Olahan Eviews
Hasil pengujian kointegrasi diatas menunjukan bahwa probabilitas dari hasil pengujian tersebut yaitu 0,0000 lebih kecil dari Mackinnon Critical Value 1\%, dan tstatistik sebesar -6,784755 lebih besar dari Mackinnon Critical Value sehingga dapat disimpulkan bahwa residual stasioner pada level maka variabel-variabel tersebut dapat dikatakan terkointegrasi.

\section{Estimasi dan Hasil Regresi Autoregressive} Distributed Lag (ARDL)

\section{Uji Lag Optimal}

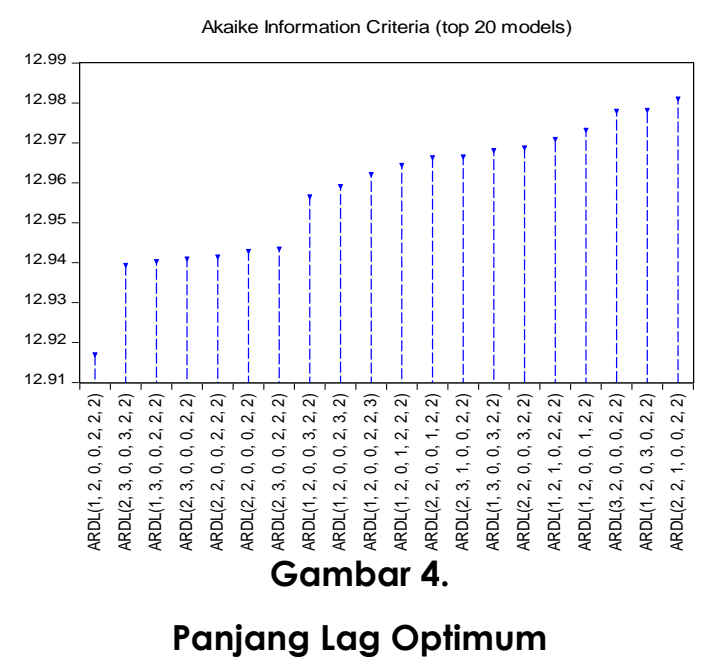

Pada gambar diatas menunjukkan model yang cocok untuk metode ARDL dalam penelitian ini adalah ARDL $(1,2,0,0,2,2,2)$ karena memiliki error yang paling kecil dibandingkan model lainnya.

\section{Bound Test}

Tabel 5.

Hasil Bound test

\begin{tabular}{|c|c|c|c|}
\hline $\begin{array}{c}\mathbf{F} \\
\text { statistik }\end{array}$ & Signifikansi & $\mathbf{I}(\mathbf{0})$ & Keterangan \\
\hline \multirow{3}{*}{7,083146} & $10 \%$ & 2,12 & \\
\cline { 2 - 3 } & $5 \%$ & 2,45 & \multirow{2}{*}{ Terkointegrasi } \\
\cline { 2 - 3 } & $2.5 \%$ & 2,75 & \\
\cline { 2 - 3 } & $1 \%$ & 3,15 & \\
\hline
\end{tabular}

Sumber: Data Olahan Eviews 
Pada tabel diatas menunjukan nilai bound test sebesar 7,083146 lebih besar dari nilai I(O) sehingga hipotesis $\mathrm{HO}$ yang mengatakan bahwa tidak ada hubungan jangka panjang ditolak, jadi dapat disimpulkan bahwaterdapat hubungan jangka panjang (kointegrasi) antar variabel.

\section{Error-correction Regression}

Hasil menunjukan bahwa errorcorrection term (ECT) memiliki koefisien sebesar $(-1,460589)$. Nilai ECT ini mencerminkan bahwa model akan menuju ketidakseimbangan dengan kecepatan sebesar 146,05 persen dikoreksi dalam satu periode triwulan.

\section{Uji Signifikansi}

Uji Simultan (F-statistik)

Tabel 6.

Hasil Uji F-statistik

\begin{tabular}{|c|c|c|c|}
\hline & $\boldsymbol{P}$-value & $\mathbf{a}$ & Keterangan \\
\hline $\begin{array}{c}\text { Jangka } \\
\text { Panjang }\end{array}$ & 0,009298 & $1 \%$ & Signifikan \\
\hline $\begin{array}{c}\text { Jangka } \\
\text { Pendek }\end{array}$ & 0,000001 & $1 \%$ & Signifikan \\
\hline
\end{tabular}

Sumber: Data Olahan Eviews

Berdasarkan tabel diatas menunjukan p-value pada jangka panjang adalah sebesar 0,009298 dan pada jangka pendek $p$-value adalah sebesar 0,000001 yang lebih kecil dari tingkat signifikansi $5 \%$, maka dapat disimpulkan bahwa pada jangka panjang dan pendek terdapat pengaruh yang signifikan antara ekspor produk industri halal, inflasi, nilai tukar, suku bunga riil, pengelvaran pemerintah dan pertumbuhan PDB secara simultan terhadap current account balance

Uji Parsial (t-statistik)

Tabel 7.

Uji t-statistik

\begin{tabular}{|c|c|c|c|}
\hline Variabel & Koefisien & $\begin{array}{c}\mathbf{p}- \\
\text { value }\end{array}$ & Keterangan \\
\hline $\begin{array}{c}\text { Ekspor Produk } \\
\text { Halal }\end{array}$ & 55,05332 & 0,0105 & $\begin{array}{c}\text { Signifikan } \\
\text { pada 5\% }\end{array}$ \\
\hline D(Ekspor) & 55,05332 & 0,0012 & $\begin{array}{c}\text { Signifikan } \\
\text { pada 5\% }\end{array}$ \\
\hline Inflasi & $-167,2648$ & 0,0853 & $\begin{array}{l}\text { Signifikan } \\
\text { pada 10\% }\end{array}$ \\
\hline $\begin{array}{c}\text { D(Inflasi) } \\
\text { PDB }\end{array}$ & $-167,2648$ & 0,0409 & $\begin{array}{c}\text { Signifikan } \\
\text { pada 5\% }\end{array}$ \\
\hline $\begin{array}{c}\text { Nilai Tukar } \\
\text { Pertumbuhan }\end{array}$ & 359,9479 & 0,1348 & $\begin{array}{c}\text { Tidak } \\
\text { Signifikan }\end{array}$ \\
\hline $\begin{array}{c}\text { Pengeluaran } \\
\text { Pemerintah }\end{array}$ & 1766,944 & 0,0169 & $\begin{array}{l}\text { Signifikan } \\
\text { pada 5\% }\end{array}$ \\
\hline $\begin{array}{c}\text { D(Pengeluaran } \\
\text { Pemerintah) }\end{array}$ & 1766,944 & 0,0020 & $\begin{array}{l}\text { Signifikan } \\
\text { pada 5\% }\end{array}$ \\
\hline $\begin{array}{c}\text { Suku Bunga Riil } \\
\text { Riil) }\end{array}$ & $-161,3022$ & 0,1428 & $\begin{array}{c}\text { Tidak } \\
\text { Signifikan }\end{array}$ \\
\hline $\begin{array}{c}\text { D(Suku Bunga } \\
\text { Signifikan } \\
\text { pada 10\% }\end{array}$ \\
\hline Sumber: Data Olikan
\end{tabular}

Sumber: Data Olahan Eviews

Berdasarkan tabel diatas maka dapat disimpulkan bahwa:

1. Pada jangka panjang variabel ekspor produk industri halal memiliki $p$-value sebesar 0,0105dan pada jangka pendek variabel $D$ (ekspor) memiliki $p$ value sebesar 0,0012 dimana nilai ini lebih kecil dari tingkat signifikansi $5 \%$. Maka dapat disimpulkan bahwa pada jangka panjang dan jangka pendek ekspor produk industri halal 
mempengaruhi current account balance di Indonesiasecara parsial.

2. Pada jangka panjang variabel inflasi memiliki p-value sebesar 0,0853dan pada jangka pendek variabel $\mathrm{D}$ (inflasi) memiliki p-value sebesar 0,0409 dimana kedua nilai ini lebih kecil dari tingkat signifikansi $10 \%$. Maka dapat disimpulkan bahwa pada jangka panjang dan jangka pendek inflasi mempengaruhi current account balance di Indonesiasecara parsial.

3. Pertumbuhan PDB pada jangka panjang memiliki p-value sebesar 0,1348 lebih besar dari nilai signifikansi 5\%. Maka dapat disimpulkan bahwa pada jangka panjang pertumbuhan PDB tidak mempengaruhi current account balance di Indonesiasecara parsial.

4. Variabel nilai tukar pada jangka panjang memiliki p-value sebesar 0,3514lebih besar dari nilai signifikansi $5 \%$. Maka dapat disimpulkan bahwa pada jangka panjang nilai tukar tidak mempengaruhi current account balance di Indonesiasecara parsial.

5. Variabel pengeluaran pemerintah pada jangka panjang memiliki $p$ value sebesar 0,0169dan pada jangka pendek variabel D/pengeluaran pemerintah) memiliki p-value sebesar 0,0020 dimana kedua nilai ini lebih kecil dari tingkat signifikansi 5\%. Maka dapat disimpulkan bahwa pada jangka panjang dan jangka pendek pengeluaran pemerintah mempengaruhi current account balance di Indonesiasecara parsial.

6. Variabel suku bunga riil pada jangka panjang memiliki p-valuedan pada jangka pendek variabel D(suku bunga riil) memiliki $p$-value sebesar 0,0707 dimana nilai ini lebih kecil dari tingkat signifikansi 10\%. Maka dapat disimpulkan bahwa pada jangka panjang suku bunga riil tidak mempengaruhi current account balance di Indonesiasecara parsial, namun pada jangka pendek suku bunga riil mempengaruhi current account balance di Indonesiasecara parsial.

\section{Koefisien Determinasi}

Berdasarkan hasil regresi didapatkan hasil $R^{2}$ pada jangka panjang adalah 0,672904 yang memiliki arti bahwa variabel ekspor produk industri halal, inflasi, nilai tukar, suku bunga riil, pengeluaran pemerintah dan pertumbuhan PDB pada jangka panjang mempengaruhi current account balance di Indonesia sebesar $67,30 \%$ dan sisanya sebesar $32,7 \%$ dijelaskan oleh faktor lainnya. Pada jangka pendek $\mathrm{R}^{2}$ adalah 0,766489 yang memiliki arti bahwa variabel ekspor produk industri halal, inflasi, nilai tukar, suku bunga riil, pengeluaran pemerintah dan pertumbuhan PDB pada jangka pendek mempengaruhi current account balance di Indonesia sebesar $76,65 \%$ dan sisanya 
sebesar 23,35\%.dijelaskan oleh faktor lainnya

Uji Autokorelasi dan Heteroskedastisitas

Uji Autokorelasi (serial LM test)

Tabel 8.

Uji Autokorelasi Breusch-Godfrey Serial LM Test

\begin{tabular}{|c|c|}
\hline F-statistik & P-value \\
\hline 0,086920 & 0,9171 \\
\hline
\end{tabular}

Sumber: Data Olahan Eviews

Hasil dari uji autokorelasi LM test diatas memiliki $p$-value 0,9171 yang lebih besar dari tingkat signifinkansi $5 \%$ sehingga dapat disimpulkan bahwa residual dari regresi ini tidak memiliki masalah autokorelasi.

Uji Heteroskedastisitas

Tabel 9.

Uji Heteroskedastisitas Breusch-paganGodfrey

\begin{tabular}{|c|c|}
\hline F-statistik & P-value \\
\hline 1,499356 & 0,1890 \\
\hline
\end{tabular}

Sumber: Data Olahan Eviews

Hasil uji heteroskedastisitas diatas memiliki p-value0, 1890 yang lebih besar dari tingkat signifinkansi 5\%. Maka dapat disimpulkan bahwa tidak ada masalah heteroskedastisitas.

\section{PEMBAHASAN}

a. Pengaruh Ekspor Produk Industri Halal terhadap Current Account Balance

Hasil menunjukan bahwa pada jangka panjang dan jangka pendek terdapat pengaruh positif yang signifikan antara ekspor produk industri halal terhadap Current Account Balance di Indonesia pada tahun 2008-2017 dengan nilai $p$-value pada jangka panjang sebesar 0,0105 dan jangka pendek sebesar 0,0012 dimana nilai probabilitas ini lebih kecil dari nilai signifikansi $5 \%$. Nilai positif terlihat dari koefisien regresi sebesar 55,05332 sehingga dapat disimpulkan bahwa hipotesis yang diajukan oleh peneliti dapat diterima dan variabel ekspor produk industri halal dapat menjelaskan dengan baik pengaruhnya terhadap current account balance di Indonesia pada tahun 2008-2017.

Hasil pada penelitian ini sesuai dengan penelitian terdahulu yang menjadi landasan teori penelitian ini, yaitu pada penelitian Calderon, Chong, \& Loayza (2002)dan Alawin (2017)yang pada salah satu kesimpulannya mengatakan bahwa peningkatan ekspor atau mengurangi impor dan menjadikan produk lokal sebagai pengganti produk asing akan membantu untuk mengurangi defisit neraca transaksi berjalan sehingga akan menaikan saldo neraca transaksi berjalan. Hasil positif menunjukan semakin meningkatnya tingkat ekspor produk industri halal maka akan meningkatkan saldocurrent account balance dan mengurangi defisit current account balance. Kegiatan ekspor ini dijelaskan pada Alquran suratAl-Jumuah ayat 10:

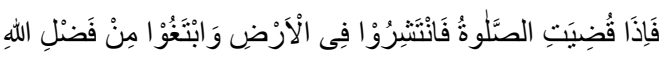

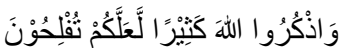

Artinya: "Apabila salat telah dilaksanakan, maka bertebaranlah kamu di bumi; carilah karunia Allah dan ingatlah Allah 
banyak-banyak agar kamu beruntung.". (Al-Jumuah: 10, Departemen Agama RI)

Pada ayat diatas dijelaskan bahwa Allah memerintahkan kepada manusia untuk bertebaran di muka bumi untuk mencari rezeki Allah. Allah memerintahkan kita untuk mencari rezeki keseluruh penjuru dunia yang dapat dilaksanakan melalui kegiatan ekspor yaitu melakukan perdagangan dengan negara-negara lain. Industri halal Indonesia harus terus ditingkatkan agar dapat bersaing di pasar Internasional, bersaing dengan negara-negara lainnya terutama negara non-muslim yang saat ini menguasai perdagangan internasional bahkan dalam industri halal. Saat ini pasar industrihalal dikuasai oleh negara non muslim seperti Brazil merupakan negara pengekspor makanan halal ke negara OKI terbesar di dunia, Perancis sebagai eksporter kosmetik halal dunia, Cina sebagai eksporter busana halal terbesar dunia dan Jerman eksporter obat-obatan halal terbesar dunia (DinarStandard synthesis and analysis; ITC Trade Map statistics). Maka dari Indonesia harus meningkatkan ekspor dan mengurangi tingkat impor yaitu mengurangi kebergantungan dengan negara lain karena Indonesia memiliki potensi dan sumber daya yang sangat besar. Dengan meningkatkan tingkat ekspor dan mengurangi tingkat impor hal ini akan mengurangi defisit neraca transaksi berjalan di Indonesia.
Pengaruh Inflasi terhadap Current Account Balance

Hasil menunjukan bahwa pada jangka panjang dan jangka pendek terdapat pengaruh yang signifikan antara inflasi dan Current Account Balance di Indonesia pada tahun 2008-2017 dilihat dari nilai $p$-value pada jangka panjang sebesar 0,0853dan jangka pendek sebesar 0,0409dimana nilai probabilitas ini lebih kecil dari nilai signifikansi $10 \%$.Berdasarkan nilai koefisien regresi sebesar -167,2648, dapat disimpulkan bahwa hipotesis yang diajukan oleh peneliti dapat diterima dan variabel inflasi dapat menjelaskan dengan baik pengaruhnya terhadap current account balance di Indonesia pada tahun 2008-2017. Hasil pada penelitian ini sesuai dengan Madura (2000) yang mengatakan bahwa perubahan laju inflasi dapat mempengaruhi perdagangan internasional.

\section{Pengaruh Pertumbuhan PDB terhadap Current Account Balance}

Hasil menunjukan bahwa antara pertumbuhan PDB dan Current Account Balance di Indonesia pada tahun 20082017 tidak terdapat pengaruh yang signifikan dilihat dari nilai $p$-value sebesar 0,1348 dimana nilai probabilitas ini lebih besar dari nilai signifikansi $5 \%$. Hal ini sesuai dengan penelitian sebelumnya yang dilakukan oleh Fitri (2014) bahwa pertumbuhan PDB tidak memiliki pengaruh yang nyata terhadap current account balance di Indonesia tahun 1990-2011. Hal ini sesuai dengan penelitian sebelumnya 
yang dilakukan oleh Fitri (2014) bahwa pertumbuhan PDB tidak memiliki pengaruh yang nyata terhadap current account balance di Indonesia tahun 1990-2011.

Pengaruh Nilai Tukar terhadap Current Account Balance

Hasil menunjukan bahwa antara nilai tukar dan Current Account Balance di Indonesia pada tahun 2008-2017 tidak terdapat pengaruh yang signifikan, hal ini terbukti dari nilai $p$-value sebesar 0.3514 dimana nilai probabilitas ini lebih besar dari nilai signifikansi $5 \%$.

Hal ini sesuai dengan penelitian yang dilakukan oleh Saputra dan Maryatmo (2016) Penelitian tersebut menyimpulkan bahwa nilai tukar rupiah terhadap dollar pada periode 2005-2015 tidak memiliki pengaruh yang positif dan signifikan terhadap current account balance di Indonesia tahun 2005-2015.

\section{Pengaruh Pengeluaran Pemerintah terhadap Current Account Balance}

Hasil menunjukan bahwa pada jangka panjang dan jangka pendek terdapat pengaruh yang signifikan antara pengeluaran pemerintah dan Current Account Balance di Indonesia pada tahun 2008-2017 berdasarkan nilai p-value pada jangka panjang sebesar 0,0169 dan jangka pendek sebesar 0,0020 dimana nilai probabilitas ini lebih kecil dari nilai signifikansi $5 \%$.Berdasarkan nilai koefisien regresi sebesar 1766,944 dapat disimpulkan bahwa hipotesis yang diajukan oleh peneliti dapat diterima dan variabel pengeluaran pemerintah dapat menjelaskan dengan baik pengaruhnya terhadap current account balance di Indonesia pada tahun 2008-2017.

Hasil pada penelitian ini sesuai dengan penelitian terdahulu yang menjadi landasan teori penelitian ini, yaitu pada penelitian Chinn, M. (2003) yang menyimpulkan bahwa pengeluaran pemerintah memiliki pengaruh positif signifikan terhadap current account balance.

\section{Pengaruh Suku Bunga Riil terhadap Current Account Balance}

Hasil menunjukan bahwa pada jangka panjang tidak terdapat pengaruh yang signifikan namun pada jangka pendek terdapat pengaruh yang signifikan antara suku bunga riil dan Current Account Balance di Indonesia pada tahun 2008-2017 berdasarkan nilai $p$-value pada jangka panjang sebesar $0,1428 d a n$ jangka pendek sebesar 0,0707dimana nilai probabilitas pada jangka panjang lebih besar dari nilai signifikansi $5 \%$ dan pada jangka pendek lebih kecil dari nilai signifikansi $10 \%$.Berdasarkan nilai koefisien regresi sebesar -161,3022, dapat disimpulkan bahwa hipotesis yang diajukan oleh peneliti dapat diterima dan variabel suku bunga riil pada jangka pendek dapat menjelaskan dengan baik pengaruhnya terhadap current account balance di Indonesia pada tahun 2008-2017.

Hasil pada penelitian ini sesuai dengan penelitian yang dilakukan oleh Saputra dan Maryatmo (2016) bahwa suku 
bunga memiliki hubungan negatif terhadap current account balance.

Pengaruh Ekspor Produk Industri Halal, Inflasi, Nilai Tukar, Pertumbuhan PDB, Pengeluaran Pemerintah Dan Suku Bunga Riil Terhadap Current Account Balance

Hasil dari pengujian secara simultan pada variabel ekspor produk industri halal, inflasi, nilai tukar, pertumbuhan PDB, pengeluaran pemerintah dan suku bunga riil terhadap current account balance di Indonesia pada tahun 2008-2017 menunjukan bahwa pada jangka panjang dan jangka pendek terdapat pengaruh yang signifikan. Hal ini terbukti dari nilai $p$-value pada jangka panjang sebesar 0,009298 dan jangka pendek sebesar 0,000001 dimana nilai probabilitas ini lebih kecil dari nilai signifikansi $5 \%$.Berdasarkan nilai koefisien regresi sebesar 3,017242, dapat disimpulkan bahwa hipotesis yang diajukan oleh peneliti dapat diterima dan variabel ekspor produk industri halal, inflasi, nilai tukar, pertumbuhan PDB, pengeluaran pemerintah dan suku bunga riil dapat menjelaskan dengan baik pengaruh current account balance di Indonesia pada tahun 2008-2017.

Hasil pada penelitian ini sesuai dengan penelitian terdahulu yang dilakukan oleh Handoko (2010) bahwa naik-turunnya neraca transaksi berjalan sangat dipengaruhi oleh faktor internal yaitu kondisi ekonomi domestik maupun faktor eksternal (perkembangan ekonomi dunia) dan Ramadhani dan Daulay (2014) yaitu secara simultan atau secara bersama-sama variabel-variabel ini pada jangka panjang dan jangka pendek memiliki pengaruh yang signifikan terhadap current account balance di Indonesia.

\section{KESIMPULAN DAN SARAN}

\section{KESIMPULAN}

Berdasarkan hasil analisis yang telah dipaparkan maka dapat disimpulkan:

1. Ekspor produk industri halal, inflasi, nilai tukar, pertumbuhan PDB, pengeluaran pemerintah dan suku bunga riil secara simultan atau secara bersama-sama pada jangka panjang dan jangka pendek memiliki pengaruh yang signifikan terhadap current account balance di Indonesia tahun 2008-2017.

2. Pada jangka panjangekspor produk industri halal dan pengeluaran pemerintah secara parsial memiliki pengaruh positif signifikan, inflasi memiliki pengaruh negatif signifikan, sedangkan nilai tukar dan pertumbuhan PDB tidak memiliki pengaruh yang signifikan terhadap current account balance di Indonesia tahun 2008-2017.Pada jangka pendek ekspor produk industri halal dan pengeluaran pemerintah memiliki pengaruh positif yang signifikan, Inflasi dan suku bunga riil memiliki pengaruh negatif signifikan, sedangkan nilai tukar dan pertumbuhan PDB tidak memiliki pengaruh yang signifikan terhadap current account balance di Indonesia tahun 2008-2017. 


\section{Saran}

1. Pemerintah Indonesia diharapkan untuk terus mengembangkan dan memperluas pasar industri halal di Indonesia serta meningkatkan komoditas ekspor produk halal Indonesia. Selain itu pemerintah Indonesia pun diharapkan untuk memiliki target untuk menjadi lima besar eksporter produk halal di dunia.

2. Diperlukan adanya sosialisasi mengenai pentingnya melakukan proses sertifikasi halal terutama pada industri makanan dan kosmetik. Pemerintah diharapkan memberikan subsidi pada proses sertifikasi halal khususnya pada UMKM.

3. Untuk penelitian selanjutnya diharapkan untuk memperluas penelitian mengenai industri halal, ekspor produk halal di Indonesia serta meneliti lebih banyak variabel yang dapat mempengaruhi current account balance

\section{DAFTAR PUSTAKA}

Abdul-Talib dan Abd-Razak. 2013. Cultivating export market oriented behavior in halal marketing: Addressing the issues and challenges in going global. Journal of Islamic Marketing

Arifin dan Hadi. 2007. Membuka Cakrawala Ekonomi, Bandung: PT Setia Purna Inves.

A Samuelson. Paul \& William D Nordhaus 1997. Mikroekonomi. Jakarta: Erlangga
Calderon, Cesar, Alberto Chong and Norman Loayza, 2000." Determinant of Current Account Deficit in Developing Countries," The World Bank Policy Research Working Paper, No. 2398

Fabozzi, Frank dan Franco Modigliani 1996, Capital Markets, $2^{\text {nd }}$ edition, Prentice hall, New Jersey

Fitri, Wulansari. (2014). Analisis Faktor-Faktor Yang Mempengaruhi Neraca Transaksi Berjalan : Studi Kasus Indonesia Tahun 1990-2011. EconomicsDevelopment Analysis Journal

Handoko, Rudi (2010). Faktor-Faktor yang Mempengaruhi Kinerja Transaksi Berjalan Indonesia. Kajian Ekonomi dan Keuangan, Volume 14 No. 4 tahun 2010.

Indonesia Halal Economy and Strategy Roadmap 2018/2019

Karl, E Case dan Fair, C Rai. 2001. Prinsipprinsip Ekonomi Makro. Jakarta: Prenhalindo

Madura, Jeff. 2006. International Corporate Finance. Keuangan Perusahaan Internasional.Edisi 8.Buku 1. Jakarta: Salemba Empat. Saputra dan Maryatmo. 2017. Pengaruh Nilai Tukar dan Suku Bunga Acuan Terhadap Neraca Transaksi Berjalan di Indonesia Periode 2005: 1-2015: 1 (Pendekatan Error Correction Model). Diakses dari ojs.vajy.ac.id. 
Seran, Sirilius. 2016. Pendidikan \&

Pertumbuhan Ekonomi versus

Kemiskinan Penduduk (Kasus

Provinsi Nusa Tenggara Timur).

Yogyakarta : Deepublish

Studenmund. 2006. Using Econometrics: A

Practical Guide. Pearson

Education, Inc. Addison Wesley.

Widjaja dan Ahmad Yani. (2000), Transaksi

Bisnis Internasional Ekspor-Impor,

Jakarta: Raja Grafindo Persada

Widjajanta, Bambang., Aristanti (2007).

Mengasah Kemampuan Ekonomi,

Bandung : 2007.

www.bi.go.id 